\title{
A Contrastive Analysis between English Idioms and Their Indonesian Translations in the Novel The Girl on the Train by Paula Hawkins (2015)
}

\author{
${ }^{1}$ Dian Novita Sari, ${ }^{2}$ Jumanto Jumanto \\ ${ }^{1,2}$ Universitas Dian Nuswantoro, Semarang \\ email address: ilhamj@dsn.dinus.ac.id
}

Article History: Submitted 30 April 2018; Accepted 3 May 2018; Published date 28 June 2018

\begin{abstract}
This study explores to find out the similarities, the differences, and the learning problems in a particular context, through a contrastive analysis. The researchers have employed a descriptive, qualitative method during the research since the aim of this study is to find out the similarities, differences, and the learning problems of English idiom and its Indonesian translation in the novel The Girl on the Train by Paula Hawkins (2015). Based on the analysis that has been done, the researchers have found out that there are 16 verbal idioms, 6 informal idioms, 4 idioms with special keywords, 2 idioms related to special themes, and 2 idiomatic pairs. About the similarities and differences, the researchers have concluded that there are 13 of 16 English idioms similar to its Indonesian translations and 3 of them different. In the informal idiom-type, there are 3 English idioms similar to its Indonesian translations and also there are 3 English idioms different from its Indonesian translations. In the idioms with special-keyword type, there is no English idiom similar to its Indonesian translation, but there are 4 English idioms that are different from its Indonesian translations. In the idioms related to special-theme type, there are 2 English idioms similar to its Indonesian translations and there is no difference. In the idiomatic-pair type, there are 2 English idioms similar to its Indonesian translations, but there is no difference in this type. Indonesian learners should note these similarities and differences between English idiom and its Indonesian translation in the novel, so they will not face learning problems or make translating mistakes when translating idioms from English into Indonesian. This is essential, especially in a translation concerning the differences between the English and Indonesian idioms.
\end{abstract}

Keywords: contrastive analysis, English and Indonesian idiom, idiom translation, Paula Hawkins' The Girl on the Train

Abstrak. Penelitian ini bertujuan menemukan persamaan dan perbedaan, serta masalah belajar dalam konteks tertentu, dengan metode analisis kontrastif. Penelitian ini bersifat kualitatif deskriptif, untuk menemukan persamaan, perbedaan, dan masalah belajar atau penerjemahan idiom dari bahasa Inggris ke dalam bahasa Indonesia dari novel The Girl on the Train karya Paula Hawkins (2015). Dari hasil analisis, ditemukan bahwa ada 16 verbal idioms, 6 informal idioms, 4 idioms with special keywords, 2 idioms related to special themes, dan 2 idiomatic pairs. Terkait dengan persamaan dan perbedaan, disimpulkan berdasarkan hasil penelitian bahwa ada 13 dari 16 idiom bahasa Inggris yang sama dengan terjemahan bahasa Indonesia, dan 3 idiom yang berbeda. Dalam tipe informal idiom, ada 3 idiom bahasa Inggris yang sama dengan terjemahan bahasa Indonesia, dan juga ada 3 idiom bahasa Inggris yang berbeda dari terjemahan bahasa Indonesia. Dalam tipe idioms with special keywords, idiom bahasa Inggris tidak ada yang sama dengan terjemahan bahasa Indonesia, tapi ada 4 idiom bahasa Inggris yang berbeda dari terjemahan bahasa Indonesia. Dalam tipe idioms related to special-theme type, ada 2 idiom bahasa Inggris yang sama dengan terjemahan bahasa Indonesia, namun tidak ada perbedaan. Dalam tipe idiomatic pair, ada 2 idiom bahasa Inggris yang sama dengan terjemahan bahasa Indonesia, namun tidak ada perbedaan. Pembelajar Indonesia harus mengenali persamaan 
dan perbedaan dari idiom bahasa Inggris dan terjemahan bahasa Indonesia yang ada di dalam novel, sehingga mereka tidak akan mengalami masalah belajar bahasa atau melakukan kesalahan penerjemahan ketika menerjemahkan idiom bahasa Inggris ke dalam bahasa Indonesia. Hal ini sangat penting, utamanya terkait dengan penerjemahan yang harus memperhatikan perbedaan yang ada antara idiom bahasa Inggris dan bahasa Indonesia.

Kata kunci: analisis kontrastif, idiom bahasa Inggris dan Indonesia, penerjemahan idiom, The Girl on the Train Paula Hawkins

\section{INTRODUCTION}

The English is an international language that is used as a foreign language besides the mother tongue; even though some countries use English as a second or official language. In Indonesia, the students get English lessons from elementary school until high school; even kids in the kindergarten do too. The aim of giving English lesson since early stage is to prepare students in the higher level of English course to be able to adapt easier because they already understand the basic. People in other countries that use English as official language, speak English almost every day. Using English as official language in a nonEnglish speaking country needs translation, so native speakers as well as foreign speakers could communicate with and understand each other. Another reason, translation is needed for various fields, one of which is a literary work.

There are various literary works from billion people around the world that use many languages in it, especially English. There are books, proses, poems, and novels. People love to read novels, as they also want to read foreign novels with foreign culture and language that consist of new experience in it. The readers will find new taste of reading; they will realize that there are other cultures, customs, and traditions around the world that are different from their own culture. But some people who do not understand a foreign language may have hard time and difficulty in reading foreign novels. That is why translation is needed. It will be very helpful when there are translated novels, as this can increase the reading passion. Not only novels but also books need to be translated into other languages for education, business, health and other fields. Translating a text from a Source Language (SL) into a Target Language (TL) is not easy. There are aspects to be considered. The translator must understand not only the source language grammatical structures but also the target language grammatical structures because every language has different structures. For example, the grammatical structures of English is different from those of Indonesian. In English they have Modifier + Head structure, while in Indonesian they have Head + Modifier structure, for an instance. The understanding on structures of two languages, the source and target languages, is very important. The translator should translate the source language into the target language as naturally as possible so that the translation can be acceptable by target readers, and the meaning is appropriately conveyed.

Another aspect of translation is culture. The translator should also understand not only the structures but also the culture, because translation and culture are related to each other. It can be stated that every language has its own structures and culture. Culture is an important element in translation. In a translating process, the translator will find some words or sentences, which are related to culture of the source language. It becomes important how the translator chooses the best words to replace a particular cultural aspect in order for target readers to read and understand the translation easily. However, of a good translated 
text is how the target readers read it as if they read the real text, not as the translated one. In this sense, Larson (1984) states,

Many problems to face in translation, these remind us that many aspects are involved in it including communication situation, cultural context of source language text, lexicon and grammar. Whatever the problems of translation are, still they have some processes to transfer the meaning of the source language into the target language. In translation, the meaning, which is being transferred, must be constant. Only the forms change. (Larson, 1984: 3)

In a translating process, the translator uses some techniques and strategies; one of them is making use of the findings of a Contrastive Analysis (CA). CA is one of linguistic methods that can be used for facilitating learners of other languages to find out some differences and similarities between the source language and the target language which usually lead to some difficulties in learning process encountered by the learner. According to Fisiak (1981: 1) "Contrastive Analysis is a sub discipline of linguistics that deals with the comparison of two or more languages in order to determine both the differences and similarities that hold between them. Furthermore, Johnson (2001) states, "However the theoretical foundations for what became known as the Contrastive Analysis Hypothesis were formulated in Lado's Linguistics Across Cultures. In this book, Lado claims that those elements that are similar to (the learner's) native language will be simple for him, and those elements that are different will be difficult. This involves describing the languages, comparing them and predicting learning difficulties" (2001: 60). Similarities usually do not cause problem, but differences do. After finding the problems, the learners can be expected to avoid making a mistake in the translating process or the process of English language learning. One of various aspects which can be analyzed by CA is idiom.

Idiom is a group of words that have different meaning from the dictionary meaning. Cruse (1986) states that Idiom is expression whose meaning cannot be accounted for as a compositional function of the meanings when they are not parts of idioms. That means even though people understand every single word, it will not be that easy to catch what exactly the sentence means. The student may have a difficulty in translating idiom if the student does not understand what idiom is. Besides, they need idiom dictionary for reference. The mistake that may happen is that the student is probably translating idiom literally, where it would be a fatal error because the meaning is not appropriately conveyed. That is why CA is needed as one of translation strategies for the students to avoid making a mistake in the translating process.

The researchers of this paper are employing Abdi's theory, which is focused on comparing two languages, then finding out the similarities and differences, in this case, of comparing idioms. According to Abdi in his book Contrastive Analysis and Error Analysis (2010), there are five steps for the systematic comparison and contrast of two languages, i.e.

1. Selection

2. Description

3. Comparison

4. Prediction

5. Verification

The researchers also use the format of point-by-point comparisons as previously suggested and applied by Jumanto (2017). The researchers choose The Girl on the Train novel by 
Paula Hawkins (2015), because there are idioms found in this novel, which become the data of this research. For example, the English idiom bundle of joy translated into Indonesian equivalent bayi, bouncing off the walls into terjaga, safe and sound into sehat dan selamat et cetera. The novel is debuted at No.1 on The New York Times Fiction Best Seller of 2015. A Contrastive Analysis plays an important role because it helps learners/translators to avoid making mistakes in the translating process. Without the understanding of the $\mathrm{CA}$ as a basic knowledge, it may cause mistakes and the result of the translated text will not be equivalent or appropriate.

\section{RESEARCH METHOD}

\section{Data and Subject}

The data of this study have been obtained from Paula Hawkins' novel The Girl on the Train (2015) and the Indonesian translation The Girl on the Train by Ingrid Nimpoeno (2016). The subject of this research is of English idioms and their Indonesian translations.

\section{Unit of Analysis}

In this research, the researchers have done a contrastive analysis between English idioms and its Indonesian translations in the novel The Girl on the Train. Moreover, the writers have analyzed the English idioms and their Indonesian translations. Therefore, idioms of both English and Indonesian, are units of analysis which are employed in this research of Contrastive Analysis.

\section{Data Collection and Data Analysis}

Before analyzing the data, the researchers choose the novel The Girl on the Train by Paula Hawkins both in English and Indonesian versions to search for the data, and then, read the novel The Girl on the Train by Paula Hawkins both in English and Indonesian versions several times. After that, the researchers define the phrases which contain idioms and which do not by reading the translations. This is done by observing the linguistic units, particularly phrases, in the translated text. When an English phrase, for example, has a different meaning from its literal meaning in the Indonesian translation, this is then defined as an idiom. A corpus of data has been obtained. And so and so, the observation process has repeated for obtaining other corpora for this research. Finally, the researchers collect as many idioms as as possible as the data for the research. Let us observe an example of obtaining English and Indonesian idioms to be compared in the Contrastive Analysis, as seen in Table 1.

Table 5 An Example of Data Collection for Contrastive Analysis

\begin{tabular}{lll}
\hline No. & English Idiom & Indonesian translation \\
\hline \multirow{2}{*}{$\begin{array}{l}\text { "No. I was frightened, at first. I didn't } \\
\text { know what he would do if I did get in } \\
\text { touch...." }\end{array}$} & $\begin{array}{l}\text { "Tidak. Mulanya aku terlalu ketakutan. Aku } \\
\text { tidak tahu apa yang akan dia lakukan jika aku } \\
\text { benar - benar menghubunginya. ...." }\end{array}$ \\
\hline
\end{tabular}

After the data have been collected, they are analyzed in five steps. First step is selection; the researchers have selected the English Idioms from the novel The Girl on the Train (English Version) by Paula Hawkins (2015) and their Indonesian translations with the same title (Indonesian Version) by Ingrid Nimpoeno (2016). The second step is description; the researchers have described the data of English Idioms and their Indonesian 
Translations under a Contrastive Analysis. The third step is comparison; the researchers have compared the data of English Idioms and their Indonesian Translations found in the novel The Girl on the Train by Paula Hawkins in a point-to-point comparison technique. The fourth step is prediction. Based on the comparisons, the researchers have found out similarities and differences between English Idioms and their Indonesian Translations. The final step is verification; the researchers have tried to make a verification by highlighting the similarities and differences as result of the contrastive analysis. In this step, the learning problems are predicted based on differences, as similarities do not usually cause learning problems.

\section{RESULTS AND DISCUSSION}

\section{Results}

Table 6 Type of Idiom According to Seidl and McMordie's Theory (1978)

\begin{tabular}{llc}
\hline No. & Type of Idiom & Number of Idiom \\
\hline 1 & Verbal Idiom & 16 \\
2 & Informal Idiom & 6 \\
3 & Idioms Containing Special Keywords & 4 \\
4 & Idioms Related to Special Themes & 2 \\
5 & Idiomatic Pairs & 2 \\
6 & Idioms Formal & - \\
7 & Idioms Related to Special Themes & - \\
8 & Idioms with Comparison & - \\
\hline Total & & $\mathbf{3 0}$ \\
\hline
\end{tabular}

Table 2 shows that the total number of English idioms and their Indonesian translations found in novel The Girl on the Train by Paula Hawkins is 30. There are 16 verbal idioms, 6 informal idioms, 4 idioms that contain special keywords, 2 idioms that are related to special themes and 2 idiomatic pairs.

After analysis on those data, the researchers have found out the similarities and differences, as can be seen in Table 3 .

Table 7 Similarities and Differences between English Idioms and Their Indonesian Translations

\begin{tabular}{llccc}
\hline No. & Types of Idiom & Similarities & Differences & Number of Idiom \\
\hline 1 & Verbal Idiom & 13 & 3 & 16 \\
2 & Informal Idiom & 3 & 3 & 6 \\
3 & $\begin{array}{l}\text { Idioms Containing } \\
\text { Keywords }\end{array}$ & - & 4 & 4 \\
4 & $\begin{array}{l}\text { Idioms Recial } \\
\text { Themes }\end{array}$ & 2 & - & 2 \\
5 & Idiomatic Pairs & 2 & - & 2 \\
\hline TOTAL & & & $\mathbf{3 0}$ \\
\hline
\end{tabular}

Table 3 shows that in the verbal-idiom type, there are 13 out of 16 English idioms which are similar to their Indonesian translations, and 3 of them which are different. In the informal-idiom type, there are 3 English idioms which are similar to their Indonesian translations and also 3 English idioms which are different from their Indonesian translations. In the type of idioms containing special keywords, there is no English idiom 
similar to their Indonesian translation, but there are 4 English idioms which are different from their Indonesian translations. In the type of idioms related to special themes, there are 2 English idioms similar to their Indonesian translations, but there is no difference. In the type of idiomatic pairs, there are 2 English idioms similar to their Indonesian translations, but there is no difference in this type.

\section{Discussion}

According to the findings or the results of this Contrastive Analysis research, the discussion shows the step-by-step techniques of contrastive analysis between English idioms and their Indonesian translations found in the novel The Girl on the Train.

\section{Verbal Idiom}

\section{a. Step 1: Selection}

The researchers have selected the following data of English Idioms and their Indonesian Translations found in the novel The Girl on the Train by Paula Hawkins to be object of Contrastive Analysis. The analysis done in this selection step can be in Table 4.

Table 8 Selection Step of Contrastive Analysis on Verbal Idiom

\begin{tabular}{llll}
\hline No. & \multicolumn{1}{c}{ English Idioms } & \multicolumn{1}{c}{ Indonesian Translations } \\
\hline 1 & Every day I tell myself not to look, and & Setiap hari kukatakan kepada diri \\
& every day I look. I can't help myself, ... & sendiri untuk tidak memandang, tapi \\
& & setiap hari aku memandang. Aku tak \\
& & kuasa... \\
2 & $\ldots$ the train starting to pick up pace as & $\ldots$ kereta mulai menambah kecepatan \\
& suburbia melts into grimy North & $\begin{array}{l}\text { ketika pinggiran kota membaur } \\
\text { menjadi London Utara yang kumuh, ... }\end{array}$ \\
\hline
\end{tabular}

\section{b. Step 2: Description}

The researchers are describing the items of English Idioms and their Indonesian Translations found in the novel The Girl on the Train by Paula Hawkins under Contrastive Analysis. The description step is done in the following account in Table 5.

Table 9 Description Step of Contrastive Analysis

\begin{tabular}{llll}
\hline No. & English Idioms & Indonesian Translations & \\
\hline \multirow{2}{*}{1} & Can't help & Tak kuasa \\
& Verb CAN'T + verb HELP & Negator TAK + adjective KUASA \\
& Pick up pace & Menambah kecepatan & \\
2 & Verb PICK UP + noun PACE & Verb MENAMBAH + noun \\
& & KECEPATAN \\
\hline
\end{tabular}

\section{c. Step 3: Comparison}

The researchers are comparing the data of English Idioms and their Indonesian Translations found in the novel The Girl on the Train by Paula Hawkins in a point-to-point comparison technique as can be seen in Table 6 and Table 7. 
Table 10 Comparison Step of Contrastive Analysis on Can't help

\begin{tabular}{|l|l|l|}
\hline No. & \multicolumn{1}{|c|}{ English Idioms } & \multicolumn{1}{c|}{ Indonesian Translations } \\
\hline 1 & Can't help & Tak kuasa \\
\hline & Meaning: to not be able to control or stop something \\
\hline Similarities & (1) Both English and Indonesian are phrases. \\
\hline Differences & $\begin{array}{l}\text { (1) English is idiomatic, Indonesian is non-idiomatic. } \\
\text { (2) English employs a verb phrase, Indonesian employs an } \\
\text { adjective phrase. }\end{array}$ \\
\hline
\end{tabular}

Table 11 Comparison Step of Contrastive Analysis on Pick up pace

\begin{tabular}{|l|l|l|}
\hline No. & \multicolumn{1}{|c|}{ English Idioms } & \multicolumn{1}{c|}{ Indonesian Translations } \\
\hline 2 & Pick up pace & Menambah kecepatan \\
\hline & Meaning: to increase tempo \\
\hline Similarities & (1) Both English and Indonesian are verb phrases. \\
\hline Differences & (1) English is idiomatic, Indonesian is non-idiomatic. \\
\hline
\end{tabular}

\section{d. Step 4: Prediction}

Based on the comparisons above, similarities and differences between English Idioms and their Indonesian Translations found in the novel The Girl on the Train by Paula Hawkins. The researchers are predicting on the findings as can be seen in Table 8 .

Table 12 Prediction Step of Contrastive Analysis

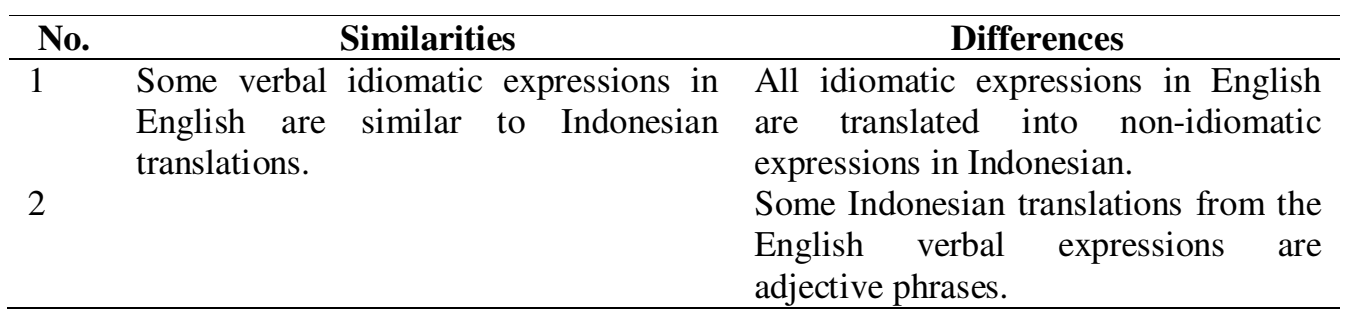

\section{e. Step 5: Verification}

In this final step, the researchers are trying to make a verification by highlighting the similarities and differences as results of the contrastive analysis. Here learning problems are predicted based on differences, as similarities do not usually cause them. The prediction of learning or translating problems in this verification step can be seen in Table 9 .

Table 13 Verification Step of Contrastive Analysis

\begin{tabular}{ll}
\hline No. & \multicolumn{1}{c}{ Predicted Learning Problems } \\
\hline 1 & Although the translated English idiomatic expressions in Indonesian are not idiomatic \\
& expressions, the learners may make mistakes by translating the phrase can't help into \\
& ${ }^{*}$ tidak bisa menolong, or the phrase pick up pace into *mengambil pergerakan, either \\
& one of which is unacceptable. \\
& $\begin{array}{l}\text { With different kinds of phrases for idiomatic expressions, the learners may make } \\
\text { mistakes when translating the English verb phrase can't help into the Indonesian verb }\end{array}$ \\
\hline
\end{tabular}

\footnotetext{
${ }^{4}$ An asterisk $(*)$ is used to indicate that a construction is not grammatically or pragmatically acceptable.
} 
phrase *tidak bisa menolong, just to maintain the similar phrase, which is then unacceptable.

\section{Idiom Containing Special Keywords}

\section{a. Step 1: Selection}

The researchers have selected the following set of data on English Idioms and their Indonesian Translations found in the novel The Girl on the Train by Paula Hawkins to be object of Contrastive Analysis. The selection step of Contrastive Analysis on this type of idioms containing special keywords can be seen in Table 10.

Table 14 Selection Step of Contrastive Analysis

\begin{tabular}{lll}
\hline No. & \multicolumn{1}{c}{ English Idioms } & \multicolumn{1}{c}{ Indonesian Translations } \\
\hline 1 & $\begin{array}{l}\text { I } \text { keep my eyes fixed } \text { on Jess, on her } \\
\text { home, ... }\end{array}$ & $\begin{array}{l}\text { Aku terus menetapkan pandangan } \\
\text { pada Jess, pada rumahnya, ... }\end{array}$ \\
2 & $\begin{array}{l}\text { I must have committed some terrible act } \\
\text { and black it } \text { out. }\end{array}$ & $\begin{array}{l}\text { Aku pasti telah melakukan semacam } \\
\text { tindakan mengerikan, lalu kehilangan } \\
\text { kesadaran total. }\end{array}$ \\
\hline
\end{tabular}

\section{b. Step 2: Description}

The researchers are describing the items of English Idioms and their Indonesian Translations found in the novel The Girl on the Train by Paula Hawkins under Contrastive Analysis in the following account. The description can be seen in Table 11.

Table 15 Description Step of Contrastive Analysis

\begin{tabular}{llll}
\hline No. & \multicolumn{1}{c}{ English Idioms } & \multicolumn{2}{c}{ Indonesian Translations } \\
\hline \multirow{2}{*}{1} & Keep eyes on & Menetapkan pandangan \\
& Verb KEEP + noun EYES + preposition & Verb MENETAPKAN + noun \\
& ON & PANDANGAN \\
\multirow{2}{*}{2} & Black out & Verb BLACK + adverb OUT & Kehilangan kesadaran total \\
& & Verb KEHILANGAN + noun \\
& & KESADARAN + adjective TOTAL \\
\hline
\end{tabular}

\section{c. Step 3: Comparison}

The researchers are comparing the data of English Idioms and their Indonesian Translations found in the novel The Girl on the Train by Paula Hawkins in a point-to-point comparison technique. The comparison Step can be seen in Table 12 and Table 13.

Table 16 Comparison Step of Contrastive Analysis on Keep eyes on

\begin{tabular}{|l|l|l|}
\hline No. & \multicolumn{1}{|c|}{ English Idioms } & \multicolumn{1}{c|}{ Indonesian Translations } \\
\hline 1 & Keep eyes on & Menetapkan pandangan \\
\hline \multirow{2}{*}{$\begin{array}{l}\text { Meaning: to watch someone or something or stay informed about the person's } \\
\text { behavior }\end{array}$} \\
\hline Similarities & Both English and Indonesian are verb phrases. \\
\hline \multirow{2}{*}{ Differences } & (1) English is idiomatic, Indonesian is non-idiomatic. \\
\cline { 2 - 3 } & (2) English idiom contains keyword 'part of body', Indonesian does not. \\
\hline
\end{tabular}


Table 17 Comparison Step of Contrastive Analysis on Black out

\begin{tabular}{|l|l|l|}
\hline No. & \multicolumn{1}{|c|}{ English Idioms } & \multicolumn{1}{c|}{ Indonesian Translations } \\
\hline 2 & Black out & Kehilangan kesadaran total \\
\hline \multicolumn{2}{|c|}{} & Meaning: undergo a sudden and temporary loss of consciousness \\
\hline Similarities & Both English and Indonesian are verb phrases. \\
\hline \multirow{2}{*}{ Differences } & (1) English is idiomatic, Indonesian is non-idiomatic. \\
\cline { 2 - 3 } & (2) English idiom contains keyword 'color', Indonesian does not. \\
\hline
\end{tabular}

\section{d. Step 4: Prediction}

Based on the comparisons above, similarities and differences between English Idioms and their Indonesian Translations found in the novel The Girl on the Train by Paula Hawkins are predicted or found out, as can be seen in Table 14 .

Table 18 Prediction Step of Contrastive Analysis

\begin{tabular}{lll}
\hline No. & \multicolumn{1}{c}{ Similarities } & \multicolumn{1}{c}{ Differences } \\
\hline 1 & Both English and Indonesian idioms are & All idiomatic expressions in English \\
& verb phrases. & are translate into non-idiomatic \\
& & expression in Indonesian. \\
2 & & Some English idioms are containing \\
& & special keywords but Indonesian \\
& translations are not. \\
\hline
\end{tabular}

\section{e. Step 5: Verification}

In this final step, the researchers are trying to make a verification by highlighting the similarities and differences as result of the contrastive analysis. Here learning problems are predicted based on differences, as similarities do not usually cause them. The prediction of learning or translating problems in this verification step can be seen in Table 15.

Table 19 Verification Step of Contrastive Analysis

\begin{tabular}{ll}
\hline No. & \multicolumn{1}{c}{ Predicted Learning Problems } \\
\hline 1 & $\begin{array}{l}\text { Although some English idioms contain special keywords such as part of body, } \\
\text { color, and animal, its Indonesian translations do not. The Indonesian learners may } \\
\text { make mistakes by translating keep eyes on into *menetapkan mata pada, instead } \\
\text { of the correct one, i.e. menetapkan pandangan. This is, therefore, unacceptable. }\end{array}$ \\
& $\begin{array}{l}\text { Although the Indonesian translation of the English idiom is not an idiomatic } \\
\text { expression, the Indonesian learners may make mistakes by translating black it out } \\
\text { into, for example, *menghitamkan semuanya, instead of the correct one, i.e } \\
\text { kehilangan kesadaran total, and this is, indeed, unacceptable. }\end{array}$ \\
\hline
\end{tabular}

\section{CONCLUSION}

Based on the data analysis, in the verbal idiom-type, there are 13 of 16 English idioms similar to their Indonesian translations, and the 3 of them are different. In the informal idiom-type, there are 3 English idioms similar to their Indonesian translations and there are 3 English idioms which are different. In the idioms containing special keywords-type, there is no English idiom similar to their Indonesian translation, but there are 4 English idioms different from their Indonesian translations. In the idioms related to special theme-type, there are 2 English idioms similar to their Indonesian translations, but there is no 
difference. In the idiomatic pair-type, there are 2 English idioms similar to their Indonesian translations, but there is no difference in this type.

Indonesian learners to be translating idioms from English into Indonesian should be aware of the differences of the set so that they will not make learning mistakes, or in this context, translating mistakes due to the differences.

\section{REFERENCES}

Cruse, D.A. (1986). Lexical Semantics. Cambridge: Cambridge University Press.

Fisiak, Jacek (ed.). (1981). Contrastive Linguistics and the Language Teacher. Oxford: Pergamon Press.

Hawkins, Paula. (2015). The Girl on the Train. New York: Penguin Group.

Jumanto. (2017). Noun Phrases, second edition: A set of Comprehensive Facts and Some Theoretical Tendencies. Yogyakarta, Indonesia: Morfalingua.

Johnson, Keith. (2001). An Introduction to Foreign Language Learning and Teaching. Edinburgh: Pearson Education Limited.

Larson, M.L. (1984). Meaning-Based Translation. Lanham: University Press of America.

Nimpoeno, Ingrid. (2016). The Girl on the Train, Paula Hawkins (2015), a translation into Indonesian by Ingrid Nimpoeno. Jakarta: Penerbit Noura Books.

Seidl, Jennifer and McMordie, W. (1978). English Idiom and How to Use Them. London: Oxford University Press. 
APPENDIX

\begin{tabular}{|c|c|c|c|c|}
\hline No & English Idioms & Locus & $\begin{array}{l}\text { Indonesian } \\
\text { Translations }\end{array}$ & Locus \\
\hline 1. & $\begin{array}{l}\ldots, \text { feel the carriage rock } \\
\text { back and forth and back and } \\
\text { forth,... }\end{array}$ & E.P.03 & $\begin{array}{l}\text {..., merasakan gerbong } \\
\text { kereta berayun-ayun } \\
\text { kedepan dan kebelakang } \\
\text { dan kedepan dan } \\
\text { kebelakang, ... }\end{array}$ & I.P.04 \\
\hline 2. & $\begin{array}{l}\text { I keep my eyes fixed on Jess, } \\
\text { on her home, ... }\end{array}$ & E.P.06 & $\begin{array}{l}\text { Aku terus menetapkan } \\
\text { pandangan pada Jess, } \\
\text { pada rumahnya,... }\end{array}$ & $\begin{array}{l}\text { I.P.07- } \\
08\end{array}$ \\
\hline 3. & $\begin{array}{l}\ldots \text { as the train starts to inch } \\
\text { forward. }\end{array}$ & E.P. 06 & $\begin{array}{l}\text {...ketika kereta mulai } \\
\text { beringsut maju. }\end{array}$ & I.P.08 \\
\hline 4. & $\begin{array}{l}\text { Every day I tell myself not to } \\
\text { look, and everyday I look. I } \\
\text { can't help myself, ... }\end{array}$ & E.P.06 & $\begin{array}{l}\text { Setiap hari kukatakan } \\
\text { kepada diri sendiri untuk } \\
\text { tidak memandang, tapi } \\
\text { setiap hari } \\
\text { memandang. Aku tak } \\
\text { kuasa... }\end{array}$ & I.P.08 \\
\hline 5. & $\begin{array}{l}\ldots \text { the train starting to pick } \\
\text { up pace as suburbia melts } \\
\text { into grimy North London, ... }\end{array}$ & E.P.07 & $\begin{array}{l}\text {... kereta } \text { mulai } \\
\text { menambah kecepatan } \\
\text { ketika pinggiran kota } \\
\text { membaur } \text { menjadi } \\
\text { London Utara yang } \\
\text { kumuh,... }\end{array}$ & I.P.08 \\
\hline 6. & $\begin{array}{l}\text {...I don't want the journey to } \\
\text { stretch out... }\end{array}$ & E.P.10 & $\begin{array}{l}\ldots \text { aku tidak ingin } \\
\text { perjalanannya molor. }\end{array}$ & I.P.13 \\
\hline 7. & $\begin{array}{l}\text { It's not just that I've put on } \\
\text { weight, or that my face is } \\
\text { puffy from the drinking, ... }\end{array}$ & E.P.11 & $\begin{array}{l}\text { Bukan hanya bobotku } \\
\text { bertambah, atau } \\
\text { wajahku bengkak gara - } \\
\text { gara alkohol,... }\end{array}$ & I.P 13 \\
\hline 8. & $\begin{array}{l}\text { It's not as if we got into a } \\
\text { fight one night at home and I } \\
\text { went for him with a golf } \\
\text { club, ... }\end{array}$ & E.P.13 & 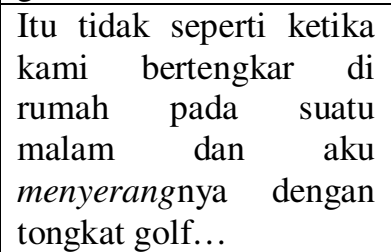 & I.P.17 \\
\hline 9. & $\begin{array}{l}\text { Or my mother, telling me } \\
\text { that she'll be in London next } \\
\text { week, she'll drop by the } \\
\text { office, ... }\end{array}$ & E.P.15 & $\begin{array}{l}\text { Atau dari ibuku, } \\
\text { mengabarkan bahwa dia } \\
\text { akan berada di London } \\
\text { minggu depan, dia akan } \\
\text { mampir ke kantor, ... }\end{array}$ & I.P.19 \\
\hline 10. & $\begin{array}{l}\text { Scott encouraged me - he } \\
\text { was over the moon when I } \\
\text { suggested it. }\end{array}$ & E.P.19 & $\begin{array}{l}\text { Scott menyemangatiku- } \\
\text { dia kegirangan ketika } \\
\text { aku mengusulkan ide } \\
\text { itu. }\end{array}$ & I.P.25 \\
\hline 11. & $\begin{array}{l}\text { I don't know how he does it. } \\
\text { I would drive me mad. }\end{array}$ & E.P.22 & 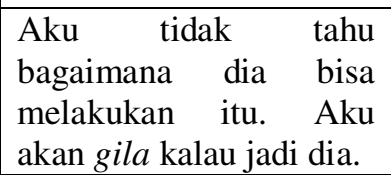 & I.P.29 \\
\hline 12. & $\begin{array}{l}\text { I'm not going to visit him, } \\
\text { I'm not going to turn up at }\end{array}$ & E.P.37 & $\begin{array}{|lrr|}\text { Aku tidak } & \text { akan } \\
\text { mengunjunginya, } & \text { aku } \\
\end{array}$ & I.P.48 \\
\hline
\end{tabular}




\begin{tabular}{|c|c|c|c|c|}
\hline & $\begin{array}{l}\text { his house and knock on the } \\
\text { door. }\end{array}$ & & $\begin{array}{lr}\text { tidak akan } & \text { muncul } \\
\text { dirumahnya } & \text { dan } \\
\text { mengetuk pintu. } & \end{array}$ & \\
\hline 13. & $\begin{array}{l}\text { I just want to go past the } \\
\text { house, roll by on the train. }\end{array}$ & E.P.37 & $\begin{array}{lr}\text { Aku hanya ingin } \\
\text { melintasi rumahnya, } \\
\text { melewatinya } \\
\text { naik kereta. }\end{array}$ & I.P.48 \\
\hline 14. & $\begin{array}{l}\text { I'm going to get off at } \\
\text { Witney. }\end{array}$ & E.P.38 & $\begin{array}{l}\text { Aku akan turun di } \\
\text { Witney. }\end{array}$ & I.P.49 \\
\hline 15. & $\begin{array}{l}\text { "... I'm not going to protect } \\
\text { you any longer, understand? } \\
\text { Just stay away from us." }\end{array}$ & E.P.41 & $\begin{array}{l}\text { “... aku tidak akan } \\
\text { melindungimu lagi, } \\
\text { mengerti? Menyingkir } \\
\text { sajalah dari kami." }\end{array}$ & I.P.54 \\
\hline 16. & $\begin{array}{l}\text {..., I was so wired when I got } \\
\text { home yesterday evening, I } \\
\text { thought I'd be bouncing off } \\
\text { the walls for hours. }\end{array}$ & E.P.46 & $\begin{array}{l}\text {.., semalam aku begitu } \\
\text { bersemangat ketika } \\
\text { pulang } \\
\text { sehingga kupikir aku } \\
\begin{array}{l}\text { akan terjaga selama } \\
\text { berjam - jam. }\end{array}\end{array}$ & I.P.61 \\
\hline 17. & $\begin{array}{l}\text { I must have committed some } \\
\text { terrible act and black it out. }\end{array}$ & E.P.67 & $\begin{array}{l}\text { Aku pasti telah } \\
\text { melakukan semacam } \\
\text { tindakan mengerikan, } \\
\text { lalu } \\
\text { kesadaran total. }\end{array}$ & I.P.88 \\
\hline 18. & $\begin{array}{l}\text { "...And during the course of } \\
\text { our enquiries, your name } \\
\text { came up." He fell silent for a } \\
\text { bit, letting this sink in. }\end{array}$ & E.P.71 & $\begin{array}{l}\text { “... Dan, saat kami } \\
\text { melakukan } \\
\text { penyelidikan, nama } \\
\text { Anda muncul." } \quad \text { Dia } \\
\text { terdiam sejenak, } \\
\text { membiarkan } \\
\text { perkataannya dipahami. }\end{array}$ & I.P.93 \\
\hline 19. & $\begin{array}{l}\text { I thought about how I would } \\
\text { sit here, bouncing my own } \\
\text { bundle of joy on my lap. }\end{array}$ & E.P.77 & $\begin{array}{l}\text { Aku membayangkan } \\
\text { betapa aku akan duduk } \\
\text { disini, melambung - } \\
\text { lambungkan bayi } \\
\text { kesayanganku sendiri di } \\
\text { atas pangkuan. }\end{array}$ & I.P.102 \\
\hline 20. & $\begin{array}{l}\text { At the time, I resented the } \\
\text { fact that it was always seen } \\
\text { as my fault, that I was the } \\
\text { one letting the side down. }\end{array}$ & E.P.78 & $\begin{array}{lr}\text { Pada saat itu aku } \\
\text { membenci fakta } & \text { bahwa } \\
\text { masalah ini } & \text { selalu } \\
\text { dipandang } & \text { sebagai } \\
\text { kesalahanku, } & \text { bahwa } \\
\text { akulah } & \text { yang } \\
\text { mengecewakan } & \\
\text { pasanganku. } & \\
\end{array}$ & I.P.103 \\
\hline 21. & $\begin{array}{l}\text { On the train on the way } \\
\text { home, as I dissect all the } \\
\text { ways that today went wrong, } \\
\ldots\end{array}$ & E.P.85 & $\begin{array}{l}\text { Di kereta dalam } \\
\text { perjalanan pulang, } \\
\text { ketika aku menganalisis } \\
\text { apa saja yang keliru hari } \\
\text { ini,... }\end{array}$ & I.P.113 \\
\hline 22. & $\begin{array}{l}\text { There she meets Scott } \\
\text { Hipwell, an independent IT } \\
\text { contractor who is friendly } \\
\text { with restaurant manager, and }\end{array}$ & E.P.87 & $\begin{array}{l}\text { Di sana dia berjumpa } \\
\text { dengan Scott Hipwell, } \\
\text { seorang kontraktor IT } \\
\text { independen } \quad \text { yang }\end{array}$ & I.P.114 \\
\hline
\end{tabular}




\begin{tabular}{|c|c|c|c|c|}
\hline & the two of them hit it off. & & $\begin{array}{l}\text { berteman dengan } \\
\text { manajer restoran itu, dan } \\
\text { mereka berdua langsung } \\
\text { cocok. }\end{array}$ & \\
\hline 23. & $\begin{array}{l}\text { I want Megan to turn up safe } \\
\text { and sound. }\end{array}$ & E.P.89 & $\begin{array}{l}\text { Aku ingin Megan } \\
\text { muncul dengan aman } \\
\text { dan selamat. }\end{array}$ & I.P.118 \\
\hline 24. & $\begin{array}{l}\text { "Yes. It won't be plain } \\
\text { sailing, Cathy," I said, ... }\end{array}$ & E.P.121 & $\begin{array}{l}\text { "Ya. Ini tidak akan } \\
\text { lancar dan mudah, } \\
\text { Cathy," kataku. }\end{array}$ & I.P.160 \\
\hline 25. & $\begin{array}{l}\text { “... I can't have people } \\
\text { coming to the door. Hanging } \\
\text { around. They'll say things } \\
\ldots \text {.." }\end{array}$ & E.P.135 & $\begin{array}{l}\text { “... tidak boleh ada } \\
\text { orang yang datang ke } \\
\text { pintu } \\
\text { Berkeliaran. rumahku. } \\
\text { akan mengatakan ini itu } \\
\text {..." }\end{array}$ & I.P.179 \\
\hline 26. & $\begin{array}{l}\text { I'm cast out. Scott's mother } \\
\text { made that clear. I'm cast out } \\
\text { and I'm disappointed, ... }\end{array}$ & E.P.137 & $\begin{array}{l}\text { Aku diusir. Ibu Scott } \\
\text { telah menytakannya } \\
\text { dengan gamblang. Aku } \\
\text { diusir dan aku kecewa, } \\
\ldots\end{array}$ & I.P.182 \\
\hline 27. & $\begin{array}{l}\text { His mobile phone starts to } \\
\text { ring, he glances at it, puts it } \\
\text { back into his pocket. "Speak } \\
\text { of the devil. She never } \\
\text { stops." }\end{array}$ & E.P.153 & $\begin{array}{lr}\text { Ponselnya } & \text { mulai } \\
\text { bordering, } & \text { dia } \\
\text { memandang } & \text { layarnya } \\
\text { sekilas, } & \text { lalu } \\
\text { memasukkannya } & \\
\text { kembali kesaku. "Baru } & \text { saja } \\
\text { membicarakannya. } & \\
\text { Ibuku tidak pernah mau } \\
\text { berhenti." }\end{array}$ & I.P.203 \\
\hline 28. & $\begin{array}{l}\text { I can see the fist coming and } \\
\text { I duck down, my hands up to } \\
\text { my head. }\end{array}$ & E.P.175 & $\begin{array}{|lrr|}\text { Aku } r \text { bisa } & \text { melihat } \\
\text { kepalan } & \text { tangan } & \text { itu } \\
\text { datang } & \text { dan } & \text { aku } \\
\text { merunduk, } & & \text { kedua } \\
\text { tanganku } & & \text { terangkat } \\
\text { unutk } & & \text { melindungi } \\
\text { kepala. } & & \\
\end{array}$ & I.P.233 \\
\hline 29. & $\begin{array}{l}\text { I told him that my marriage } \\
\text { broke down, that I was } \\
\text { depressed, and I'd always } \\
\text { been a drinker, but that } \\
\text { things just got out of hand. }\end{array}$ & E.P.191 & $\begin{array}{l}\text { Kukatakan } \\
\text { perkawinanku hancur, } \\
\text { aku mengalami depresi, } \\
\text { dan aku selalu suka } \\
\text { menenggak alkohol, tapi } \\
\text { segalanya menjadi tak } \\
\text { terkendali. }\end{array}$ & I.P.254 \\
\hline 30. & $\begin{array}{l}\text { "No. I was frightened, at } \\
\text { first. I didn't know what he } \\
\text { would do if I did get in } \\
\text { touch..." }\end{array}$ & E.P.212 & $\begin{array}{l}\text { "Tidak. Mulanya aku } \\
\text { terlalu ketakutan. Aku } \\
\text { tidak tahu apa yang akan } \\
\text { dia lakukan jika aku } \\
\text { benar - benar } \\
\text { menghubunginya...." }\end{array}$ & I.P.282 \\
\hline
\end{tabular}

